Ci. e Nat., Santa Maria, v. 43, e3, 2021 • https://doi.org/10.5902/2179460X40961

Submitted: 04/03/2020 • Accepted: 03/11/2020 • Published: 30/01/2021

Biology (Plant-Microorganism Interaction)

\title{
Suppression of Pratylenchus brachyurus and soybean growth inoculated with arbuscular mycorrhizal fungus
}

\author{
Edicarla Trentin ${ }^{(0)}$, Valéria Ortaça Portela' ${ }^{\circledR}$, Juliane Schmitt ${ }^{1}{ }^{(0}$, Reyllis Kiefer

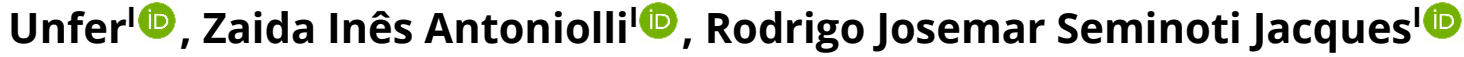

' Universidade Federal de Santa Maria, Santa Maria, RS, Brasil

\begin{abstract}
Arbuscular mycorrhizal fungi perform a variety of plant-beneficial processes including increased resistance to disease. The objective of this work was to study arbuscular mycorrhizal fungus RhizoGlomus clarum effect on phytonematode Pratylenchus brachyurus suppression and on soybean plants growth. Two experiments were performed under greenhouse conditions. First soybean plants growth was evaluated in mycorrhizal fungi presence and absence. In the second experiment phytonematode damage in soybean cultivated in mycorrhizal fungi presence and absence was evaluated. During soybean flowering was evaluated mycorrhizal colonization, dry matter, nodulation, chlorophyll and nutrient content in plant tissue, nematodes number in soil and root penetration, and nematode reproduction factor was obtained, $R$. clarum mycorrhizal colonization reduced by $64 \%$ the number of nematodes penetrated in roots and increased soybean plants nodulation, nutrient absorption and dry matter accumulation. The stimulation to mycorrhization is a strategy to reduce damage caused by Pratylenchus brachyurus to soybean plants.
\end{abstract}

Keywords: Glycine max; Rhizoglomus clarum; Inoculant; Mycorrhization; Phytonematode

\section{INTRODUCTION}

Soil microorganisms are very important for agricultural systems and are directly related to soil quality and soybean yield (Glycine max L. Merril) (MONDANI et al., 2019). Mutualistic association between arbuscular mycorrhizal fungi (AMF) and plants provides an increase soil volume explored by the root system (MATSUO et al., 2012; SCHNEIDER et al., 2016; RASMUSSEN et al., 2019), increasing water and nutrients absorption (SMITH e READ, 2008; HASHEM et al., 
2018). In addition to the direct benefits for soybean growth, AMF presence also has a positive influence on soil physical and chemical properties (PEREIRA et al., 2013; SALGADO et al., 2016; EL MUJTAR et al., 2019), biological activity near roots (WANG et al., 2011) and acts against biotic and abiotic stress (SALGADO et al., 2016).

Phytonematoids are among the most important biotic factors in soybean cultivation and have become a serious problem for many crops in recent years (BRIDA et al., 2017). Several nematodes species harm soybean, but the Pratylenchus brachyurus have been highlighted by the severity of the damage caused to the plants and by the rapid increase of the infested area (FREITAS et al., 2017). This nematode is responsible for lesions formation in plants roots due to its feeding habits, movement, and toxins and enzymes injection into the root cortex (SANTANA-GOMES et al., 2014). Thus, plants water and nutrient absorption processes are affected, as well as infection by secondary pathogens is facilitated (LIMA et al., 2015; FREITAS et al., 2017).

Alternatives for phytonematode control have been studied, among them, suppression by AMF (TCHABI et al., 2016; RASMUSSEN et al., 2019). These fungi are essential for productive systems sustainability, but their populations have been reduced due to inadequate management practices (CASTILLO et al., 2016). In Brazil, soybean is usually cultivated with low quality crop rotation and use of large amounts of fertilizers and agrochemicals (BELO et al., 2012) which impairs AMFs and favors phytonematodes (PASARIBU et al., 2013).

Several studies have used these fungi as antagonists to parasitic nematodes from other agricultural crops, but not to soybean (ELSEN et al., 2008; VOS et al., 2012). Recently in Brazil, Rootella BR ${ }^{\mathrm{TM}}$ mycorrhizal inoculant was registered in Livestock and Food Supply Ministry (Ministério da Agricultura, Pecuária e Abastecimento - MAPA) for use in soybean and corn crops (AGROLINK, 2019). However, studies involving $P$. brachyurus suppression by mycorrhizal fungi in soybean crop are very scarce or nonexistent. Considering this gap of 
information and P. brachyurus importance for soybean cultivation in Brazil, and in the world, the objective of this work was to study the effect of arbuscular mycorrhizal fungus RhizoGlomus clarum on Pratylenchus brachyurus suppression and soybean plants growth.

\section{MATERIAL AND METHODS}

\subsection{Soil}

A Typic Hapludalf was collected in the $0-20 \mathrm{~cm}$ depth layer excluding the surface vegetal residues in a natural pasture area with no crop history. This soil was sterilized by autoclaving for 4 hours at $121^{\circ} \mathrm{C}$, dried at room temperature sieved and separated into pots containing $3.5 \mathrm{~kg}$ of soil. Subsequently, autochthonous microorganisms reinoculation was performed, by the addition of solution extracted from the same non-sterile soil, passing through 500 mesh sieves to exclude presence of nematodes and AMF spores (HAYMANN e MOSSE, 1971). To raise soil $\mathrm{pH}$, calcium carbonate $\left(\mathrm{CaCO}_{3}\right)$ and magnesium carbonate $\left(\mathrm{MgCO}_{3}\right)$ were added in 3:1 $\mathrm{Ca}$ and $\mathrm{Mg}$ molar ratio and the soil was then incubated for 40 days at a humidity equivalent to $70 \%$ of field capacity.

Soil fertilization was carried out according to Soil Chemistry and Fertility Commission - CQFS-RS/SC (2016), adding 50\% of P recommended dose so that there was no mycorrhizal colonization inhibition of plants according to Ferreira et al. (2015) that used both same soil and fungus. Before sowing the soybean $22.9 \mathrm{mg} \mathrm{kg}^{-1} \mathrm{P}$ and $28 \mathrm{mg} \mathrm{kg}^{-1} \mathrm{~K}$ were added to soil as a $\mathrm{KH}_{2} \mathrm{PO}_{4}$ solution. Fertilized soil presented the following characteristics: clay (densimeter) $170 \mathrm{~g} \mathrm{~kg}^{-1} ; \mathrm{pH}$ in water (1:1) 4.9; $\mathrm{P}\left(\right.$ Mehlich-1 $\left.^{-1}\right) 35.7 \mathrm{mg} \mathrm{dm}^{-3} ; \mathrm{K}_{\text {(Mehlich-1 }}$ ) $196 \mathrm{mg} \mathrm{dm}^{-3}$; organic matter (Walkley-Black) $26 \mathrm{~g} \mathrm{~kg}^{-1}$; exchangeable Al (KCl $\left.1 \mathrm{~mol} \mathrm{~L}^{-1}\right) 1.1 \mathrm{cmolc} \mathrm{dm}^{-3}$; Ca $\left(\right.$ Mehlich-1) $3.6 \mathrm{cmol}_{\mathrm{c}} \mathrm{dm}^{-3} ; \mathrm{Mg}\left(\right.$ Mehlich $\left.^{-1}\right) 1.8 \mathrm{cmol}_{\mathrm{c}} \mathrm{dm}^{-3}$; Base Saturation 
40.7\%; Saturation by Al 15.5\%; Zn(Mehlich-1) $1.4 \mathrm{mg} \mathrm{dm}^{-3}$; Cu (Mehlich $\left.{ }^{-1}\right) 0.2 \mathrm{mg}$ $\mathrm{dm}^{-3} ; \mathrm{S}$ available $\left[\mathrm{Ca}\left(\mathrm{H}_{2} \mathrm{PO}_{4}\right)_{2}\right] 31 \mathrm{mg} \mathrm{dm}^{-3}$; and $\mathrm{B}$ (hot water) $0.7 \mathrm{mg} \mathrm{dm}^{-3}$.

\subsection{Biological Material}

Nematode inoculum was composed of a pure population of Pratylenchus brachyurus (Godfrey, 1929) Filipjev, Schuurmans Stekhoven 1941 multiplied in sorghum plants (Sorghum bicolor (L.) Moench) cultivar BRS 506, in a greenhouse. Inoculum preparation was carried out by roots grinding, according to technique modified by Bonetti e Ferraz (1981).

Initial inoculum of AMF RhizoGlomus clarum (TH Nicolson; NC Schenck) C. Walker e A. Schüßler (formerly Rhizophagus clarus and Glomus clarum) was obtained from International Glomeromycota Culture Collection (CICG) of Regional University of Blumenau, Santa Catarina State, Brazil and multiplied in culture trap of Brachiaria decumbens. Soil spore extraction was performed according to the methodology described in Ferreira et al. (2015). Spores were counted using a stereomicroscope microscope and separated in 100 units aliquots in microtubes.

\subsection{Experiment}

Two experiments were conducted in a greenhouse, arranged in a completely randomized design, with eight replications per treatment using the same soil and following the same installation, conduction and evaluation procedures. In the first experiment, soybean growth was evaluated in two treatments: mycorrhizal fungus RhizoGlomus clarum presence and absence in soil. In the second experiment, AMF effect on Pratylenchus brachyurus nematode suppression in soybean plants was evaluated, with all pots inoculated with the nematode and soybean cultivated in $R$. clarum presence or absence. 
The sowing was carried out with soybean seeds, cultivar Nidera 5909. which were inoculated with Bradyrhizobium spp., according to technical recommendations. Under the seeds, approximately $100 \mathrm{R}$. clarum viable spores were added per culture pot. In the soybean V3 stage nematoid inoculation was performed. Three approximately $5 \mathrm{~cm}$ deep orifices were opened around seedlings, in which $3 \mathrm{~mL}$ of a suspension containing 2000 P. brachyurus eggs and juveniles, diluted in $25 \mathrm{~mL}$ of water, were added. During the experiment, pots irrigation was performed daily with distilled water, aiming to maintain the soil with approximately $70 \%$ of the field capacity.

\subsection{Analysis}

The evaluations were carried out on soybean flowering. Plants relative chlorophyll content was determined on a portable chlorophyllometer (SPAD-502 Minolta Japan). Readings were taken on central trifolium of last fully developed leaf, at 5 points of leaf of each plant, Shoot, roots and nodules dry matter was determined in a greenhouse with forced air circulation, at $65{ }^{\circ} \mathrm{C}$, until constant mass. Mycorrhizal colonization was evaluated by Giovannetti e Mosse (1980) methodology, by roots discoloration with $10 \% \mathrm{KOH}$ and subsequent Trypan blue $0.05 \%$ staining. Mycorrhizal colonization percentage of the roots system was evaluated by the presence of hyphae or vesicles presence in 20 segments of the $0.5 \mathrm{~cm}$ in length, segments arranged between slides and coverslips, and visualized with a microscope at $40 \mathrm{x}$ of magnification. The $\mathrm{P}, \mathrm{K}, \mathrm{Ca}, \mathrm{Mg}, \mathrm{Fe}, \mathrm{Mn}$, $\mathrm{Cu}, \mathrm{Zn}$ and $\mathrm{S}$ concentrations of the shoot were determined after nitric-perchloric digestion in an atomic absorption spectrophotometer (932 AA, GBC, Australia) (EMBRAPA, 1997). $\mathrm{N}$ content was determined by the Kjeldahl-1 method after sulfur digestion (BREMNER e MULVANEY, 1982).

Nematodes number in soil was determined according to Noronha et al. (2017), by the centrifugal flotation method in sucrose solution. Evaluation of 
nematode penetration in the root system followed the root coloring methodology of Byrd et al. (1983). Roots were arranged between two glass slides under a microscope with a 40x magnification for counting $P$. brachyurus penetrated number. Nematode reproduction factor (FR = FP / IP) was calculated by dividing the final nematode population in pot (soil + roots) (FP) and the initial inoculated population by pot (IP).

The data were submitted to analysis of variance (ANOVA) and means were compared by t test (LSD) at 5\% error probability, with SISVAR software (FERREIRA, 2014).

\section{RESULTS AND DISCUSSION}

\subsection{Experiment I: Soybean Growth}

Soybean mycorrhization in fungus RhizoGlomus clarum presence was efficient, with approximately $100 \%$ of root segments with fungal hyphae and $60 \%$ of vesicle segments (data not shown). In high $\mathrm{P}$ levels soils root mycorrhizal colonization can be inhibited (SMITH e REED, 2008). In the present study, although the $P$ level of $35.7 \mathrm{mg} \mathrm{dm}^{-3}$ is considered as very high by Chemistry and Soil Fertility Commission - CQFS-RS/SC (2016) there was no mycorrhizal colonization inhibition. This fact is in agreement with Ferreira et al. (2015), which used same soil and mycorrhizal fungal specie. No mycorrhizal colonization was observed in plants cultivated in $R$. clarum absence. The presence of $R$. clarus in the soil stimulated the growth of soybean plants (Figure 1). The dry matter values of shoot and root system, plant height and stem diameter were higher in plants inoculated with mycorrhizal fungus. A similar result was found by Pereira et al. (2013), which observed that the presence of AMF Gigaspora margarita and Glomus clarum exerts a positive influence on the growth and development of soybean plants, quantified through the dry matter of the shoot and the root system. 
Figure 1 - Shoot and root dry mass (a), plant height and stem diameter (b), nodules number and dry mass (c) and chlorophyll relative index (SPAD) (d) at soybean flowering, grown in arbuscular mycorrhizal fungus RhizoGlomus clarum presence (+AMF) and absence (-AMF). Data presented are averages of eight replicates. Means followed by same letter were not significantly different according to $t$ test (LSD) at $5 \%$ error probability.

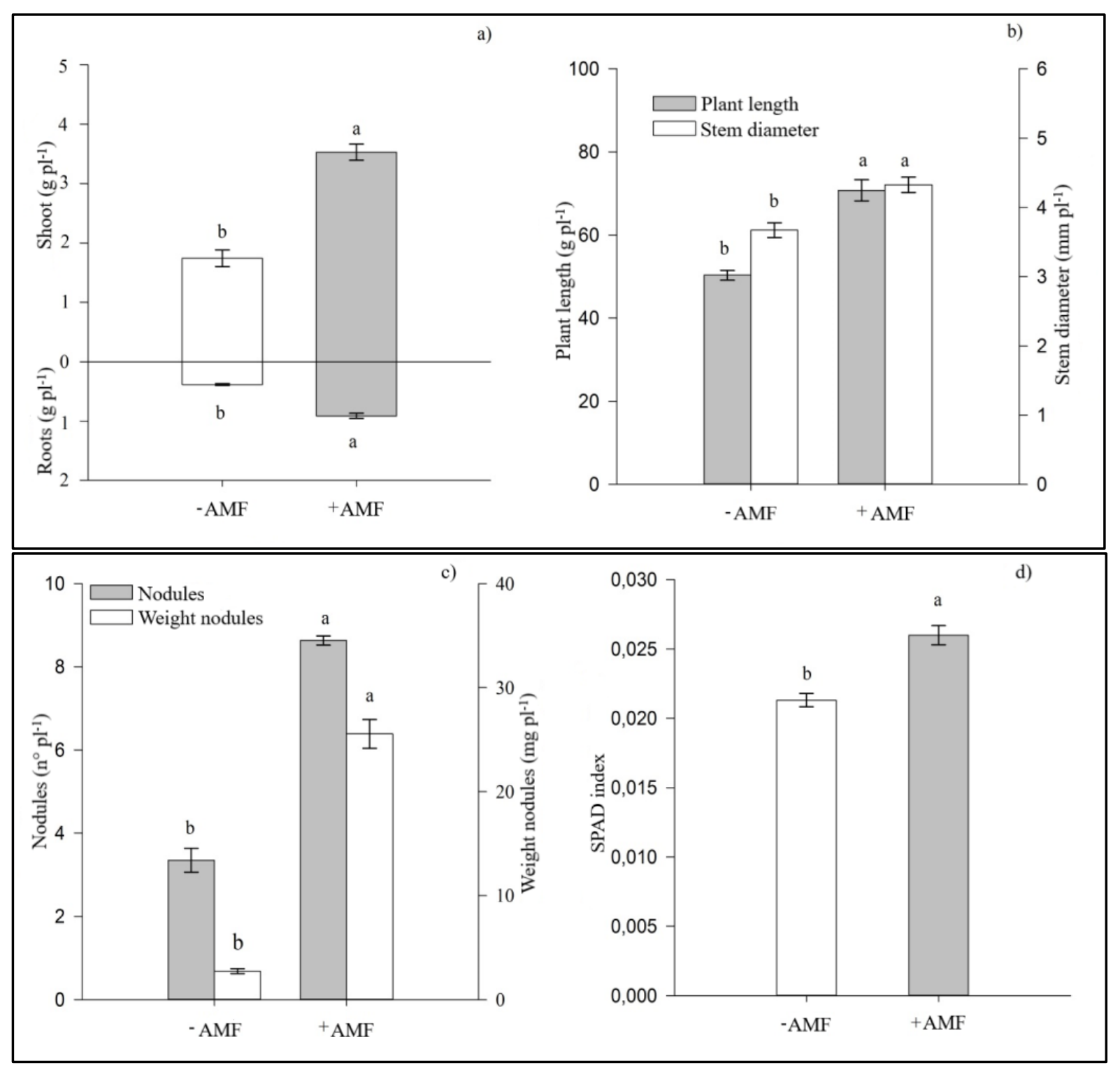

Mycorrhizal colonization resulted in a nodulation stimulus (Figure 1c), with a $40 \%$ increase in number and $87 \%$ in nodules mass. The mycorrhization favors biological activity in the rhizosphere and consequently, nitrogen-fixing bacteria (ANZANELLO, SOUZA, CASAMALI, 2011). Relative chlorophyll index was also $20 \%$ higher in plants inoculated with 
mycorrhizal fungus (Figure 1d), which may be related to higher biological $\mathrm{N}$ fixation and higher nutrient intake due to AMF presence.

The plants without mycorrhizae had higher shoot nutrients concentrations as N, P, $\mathrm{Ca}, \mathrm{Mg}, \mathrm{Mn}$ and $\mathrm{Zn}$ (Table 1). This result can be explained by the concentration effect due to lower growth. When accumulated value was calculated, all nutrients were absorbed in greater quantity by plants inoculated with mycorrhizal fungus. Bressan et al. (2001) evaluating AMFs Gigaspora margarita, Glomus etunicatum and Glomus clarum inoculation effect on sorghum and soybean plants, observed that AMF presence increased $N, P, K, Z n$ and $\mathrm{Cu}$ concentration in both plants and similarly $\mathrm{Ca}, \mathrm{Mg}$ and $\mathrm{Mn}$ concentrations were higher in the treatment without inoculation, due to nutrient dilution in plant tissue. Results observed in the present work demonstrate that mycorrhization stimulated soybean plants growth and was not affected by high P levels in soil.

Table 1 - Nutrients concentration and accumulation in soybean shoot in presence and absence of arbuscular mycorrhizal fungus (AMF) Rhizoglomus clarum.

\begin{tabular}{|c|c|c|c|c|c|}
\hline \multirow{2}{*}{ Nutrient } & \multirow{2}{*}{ AMF } & \multicolumn{2}{|c|}{ Concentration } & \multicolumn{2}{|c|}{ Accumulation } \\
\hline & & $\left(\mathrm{g} \mathrm{kg}^{-1}\right)$ & CV\% & (g plant $^{-1}$ ) & CV\% \\
\hline$N$ & $\begin{array}{l}- \\
+\end{array}$ & $\begin{array}{l}45.19 a \\
30.87 b\end{array}$ & 2.39 & $\begin{array}{c}85.41 \mathrm{~b} \\
101.16 \mathrm{a}\end{array}$ & 3.31 \\
\hline$P$ & $\begin{array}{l}- \\
+\end{array}$ & $\begin{array}{l}2.17 \mathrm{a} \\
1.74 \mathrm{~b}\end{array}$ & 3.98 & $\begin{array}{l}4.03 \mathrm{~b} \\
5.72 \mathrm{a}\end{array}$ & 1.95 \\
\hline K & $\begin{array}{l}- \\
+\end{array}$ & $\begin{array}{l}10.39 \mathrm{~b} \\
13.52 \mathrm{a}\end{array}$ & 1.67 & $\begin{array}{l}20.12 \mathrm{~b} \\
44.42 \mathrm{a}\end{array}$ & 1.53 \\
\hline $\mathrm{Ca}$ & $\begin{array}{l}- \\
+\end{array}$ & $\begin{array}{l}6.44 a \\
4.42 b\end{array}$ & 4.19 & $\begin{array}{l}12.34 \mathrm{~b} \\
14.55 \mathrm{a}\end{array}$ & 4.47 \\
\hline $\mathrm{Mg}$ & $\begin{array}{l}- \\
+\end{array}$ & $\begin{array}{l}3.83 \mathrm{a} \\
3.45 \mathrm{~b}\end{array}$ & 4.50 & $\begin{array}{l}7.45 \mathrm{~b} \\
12.92 \mathrm{a}\end{array}$ & 5.45 \\
\hline
\end{tabular}

Continuation... 
Table 1 - Conclusion...

\begin{tabular}{|c|c|c|c|c|c|}
\hline \multirow{2}{*}{ Nutrient } & \multirow{2}{*}{ AMF } & \multicolumn{2}{|c|}{ Concentration } & \multicolumn{2}{|c|}{ Accumulation } \\
\hline & & $\left(\mathrm{g} \mathrm{kg}^{-1}\right)$ & CV\% & (g plant $\left.^{-1}\right)$ & CV\% \\
\hline \multirow[b]{2}{*}{$S$} & - & $1.87 \mathrm{~b}$ & \multirow[b]{2}{*}{3.15} & $3.53 \mathrm{~b}$ & \multirow[b]{2}{*}{0.38} \\
\hline & + & $2.36 \mathrm{a}$ & & $7.59 a$ & \\
\hline \multirow[b]{2}{*}{$\mathrm{Cu}$} & - & $8.79 \mathrm{~b}$ & \multirow[b]{2}{*}{3.03} & $17.00 \mathrm{~b}$ & \multirow[b]{2}{*}{0.53} \\
\hline & + & $11.17 \mathrm{a}$ & & $35.95 \mathrm{a}$ & \\
\hline \multirow{2}{*}{$\mathrm{Fe}$} & - & $86.23 \mathrm{a}$ & 3.64 & $165.10 \mathrm{~b}$ & \multirow{2}{*}{3.52} \\
\hline & + & $93.08 \mathrm{a}$ & & & \\
\hline \multirow{2}{*}{$\mathrm{Mn}$} & 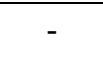 & $238.14 \mathrm{a}$ & \multirow{2}{*}{1.89} & $455.55 \mathrm{~b}$ & \multirow{2}{*}{1.25} \\
\hline & + & $222.17 b$ & & 737.49 a & \\
\hline \multirow{2}{*}{$\mathrm{Zn}$} & - & $42.92 \mathrm{a}$ & \multirow[t]{2}{*}{3.95} & $80.22 \mathrm{~b}$ & \multirow[t]{2}{*}{0.25} \\
\hline & + & $36.73 b$ & & $118.44 \mathrm{a}$ & \\
\hline
\end{tabular}

Data presented as averages of eight replicates. Means followed by the same letters did not present statistical differences between treatments with and without AMF inoculation for each nutrient by test (LSD) at $5 \%$ probability of error.

\subsection{Experiment II: Phytonematode suppression}

An efficient mycorrhizal colonization in plants is a prerequisite for a possible nematode suppression effect (ELSEN et al., 2008; SCHOUTEDEN et al., 2015). In the present study, $R$. clarum efficiently colonized soybean root system even in Pratylenchus brachyurus presence, resulting in 100\% colonized roots by hyphae and 35\% by vesicles (data not shown). Again, no mycorrhizal colonization was observed in plants not inoculated with $R$. clarum.

Mycorrhization stimulated soybean growth even when soil was infested with phytonematodes. Dry mass increase was of $18 \%$ in shoot and $20 \%$ in roots (Figure 2a). No statistically significant differences were observed in plant height. However, values tended to be higher in treatment with AMF presence (Figure 2b). Regarding stem diameter, once again plants with mycorrhizae presented a significantly better performance. Talavera et al. (2001) observed that G. mosseae presence increased carrot plants mass and reduced in 49\% nematodes Pratylenchus penetrans density in soil. Relative chlorophyll index was higher in the treatment with $R$. clarum inoculation (Figure 
$2 \mathrm{~d})$. This can be a consequence of better nutritional status of plants inoculated with mycorrhizal fungus, also a result of higher nodulation observed in root system (Figure 2c). This result evidences mycorrhization beneficial effects on phytonematode damage attenuation. According to Asmus e Ferraz (2002) there was a reduction in soybean leaves chlorophyll content in nematode Heterodera glycines presence.

Figure 2 - Shoot and root dry mass (a), plant height and stem diameter (b), nodules number and dry mass (c) and relative chlorophyll index (d) at soybean plants flowering cultivated in soil infested by Pratylenchus brachyurus nematode, in arbuscular mycorrhizal fungus RhizoGlomus clarum presence (+AMF) and absence (-AMF). Data presented as averages of eight replicates. Means followed by same letter were not significantly different according to $t$ test (LSD) at $5 \%$ probability of error.

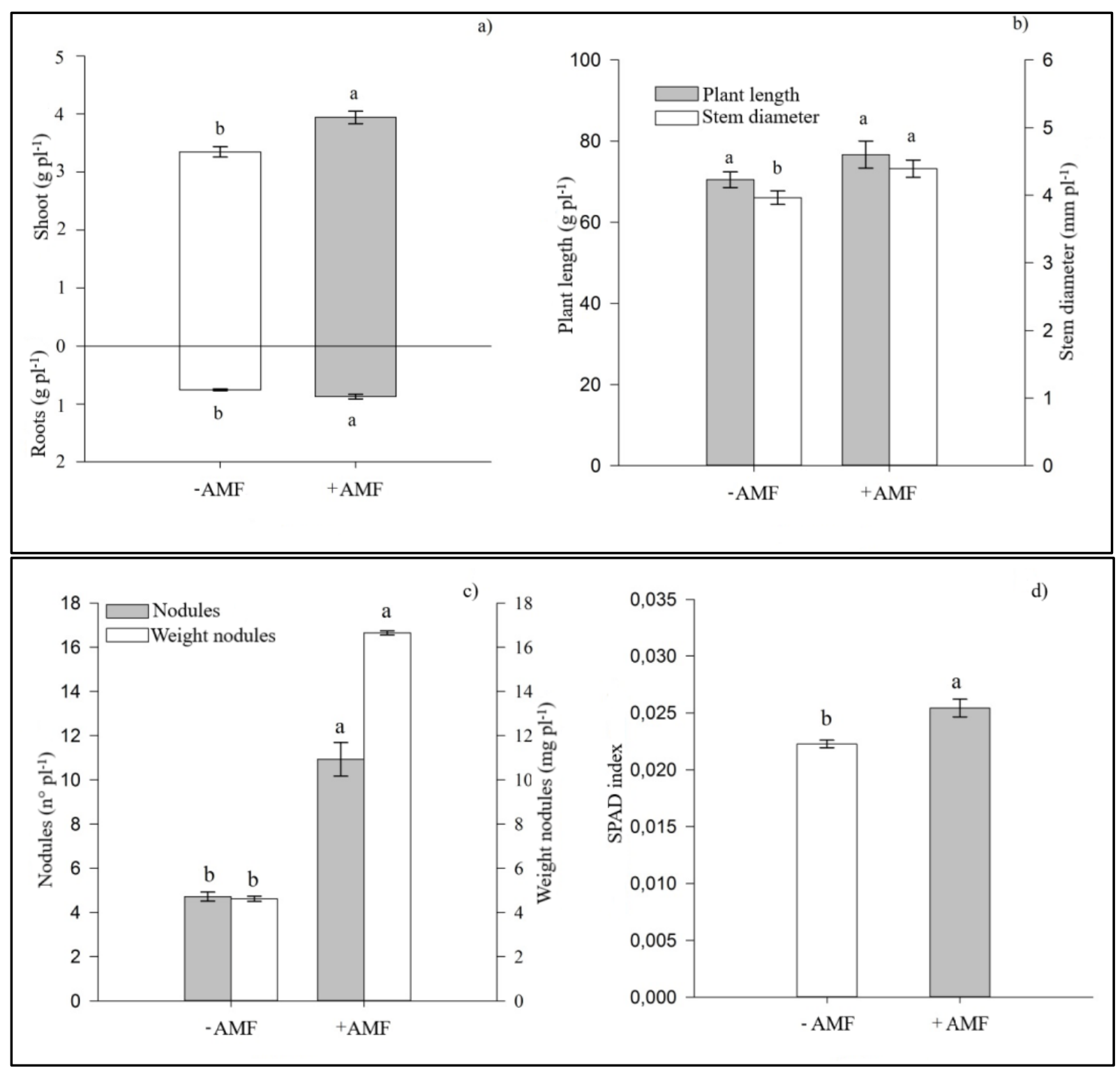

Ci. e Nat., Santa Maria, v.43, e3, 2021 
Table 2 - Nematodes number in roots and soil, and reproduction factor (RF) in soybean cultivated in soil infested by Pratylenchus brachyurus phytonematode and inoculated or not with arbuscular mycorrhizal fungus Rhizoglomus clarum

\begin{tabular}{lccc}
\hline \multicolumn{1}{c}{ Treatments } & Nematodes in 50 g roots & Nematodes in 100g soil & Reproduction Factor \\
\hline P. brachyurus & $19.75 \mathrm{a}$ & $24.99 \mathrm{~b}$ & $1.43 \mathrm{~b}$ \\
P. brachyurus + AMF & $7.11 \mathrm{~b}$ & $60.51 \mathrm{a}$ & $4.22 \mathrm{a}$ \\
CV\% & 10.65 & 15.47 & 13.64 \\
\hline
\end{tabular}

Data presented as averages of eight replicates. Means followed by same letters in the column did not present statistical differences between treatments with and without $R$. clarum inoculation, by t test (LSD) at $5 \%$ of error probability

The AMF presence, besides contributing to plant nutrition, induces the activation of plant defense mechanisms against nematode damages (PEREIRA et al., 2013; SALGADO et al., 2016; WANG et al., 2011). These authors differentiated possible AMF modes of action against nematodes: increased competition for space and food in root tissue; growth stimulus, nutrition and morphological changes in plants, such as increased tissue lignification and suberization, and increased water and nutrients absorption by the root system; biochemical changes related to defense mechanisms and induced resistance of plants, such as modification in root exudates composition, phenolic compounds, hormones and phytoalexins production, which act as repellents to nematodes; and development of an antagonistic microbiota.

Total P. brachyurus number in soil was 59\% higher when plants were inoculated with $R$. clarum (Table 2). This result can be explained by phytonematodes lower penetration in roots due to AMF presence, resulting in a greater number in soil. Due to the greater nematodes amount present in soil. Reproduction Factor was higher in mycorrhizal fungus presence. Since it is superior to 1 , we can infer that the cultivar is susceptible to $P$. brachyurus.

Mycorrhization also improved nutritional status from plants infested by the nematodes (Table 3). Increases in N, P, Ca, Cu, Fe, Mn and $\mathrm{Zn}$ in soybean shoot were observed. Only $\mathrm{K}$ and $\mathrm{Mg}$ were absorbed in greater amounts in the treatment without 
mycorrhizal fungus. This result can be attributed to plants metabolic disturbances caused by nematode presence. Plants reaction to nematodes is highly variable and dependent on a number of factors, such as nematode species, host plant and both soil and climatic conditions (ELSEN et al., 2008; CAMERON et al., 2013; SCHOUTEDEN et al., 2015).

Table 3 - Nutrients concentration and accumulation evaluated at flowering in soybean shoot cultivated in soil infested by nematode Pratylenchus brachyurus and inoculated or not with arbuscular mycorrhizal fungus Rhizoglomus clarum

\begin{tabular}{|c|c|c|c|c|c|}
\hline Nutrient & AMF & Concentration $\left(\mathrm{g} \mathrm{kg}^{-1}\right)$ & CV\% & Accumulation (g plant ${ }^{-1}$ ) & CV\% \\
\hline \multirow{2}{*}{$\mathrm{N}$} & - & $37.52 \mathrm{a}$ & \multirow{2}{*}{2.20} & $122.68 \mathrm{~b}$ & \multirow{2}{*}{0.10} \\
\hline & + & $35.46 \mathrm{~b}$ & & $132.39 \mathrm{a}$ & \\
\hline \multirow{2}{*}{$P$} & - & $1.93 \mathrm{~b}$ & \multirow{2}{*}{2.39} & $6.27 b$ & \multirow{2}{*}{2.91} \\
\hline & + & $2.09 a$ & & $8.25 \mathrm{a}$ & \\
\hline \multirow{2}{*}{ K } & - & $13.57 \mathrm{a}$ & \multirow{2}{*}{2.50} & 44.66 a & \multirow{2}{*}{2.30} \\
\hline & + & $10.02 \mathrm{~b}$ & & $37.61 \mathrm{~b}$ & \\
\hline \multirow{2}{*}{$\mathrm{Ca}$} & - & $5.45 \mathrm{a}$ & \multirow{2}{*}{6.73} & $18.64 \mathrm{~b}$ & \multirow{2}{*}{2.82} \\
\hline & + & $5.32 \mathrm{a}$ & & $20.21 \mathrm{a}$ & \\
\hline \multirow{2}{*}{$\mathrm{Mg}$} & - & $4.30 \mathrm{a}$ & \multirow{2}{*}{4.93} & $14.35 \mathrm{a}$ & \multirow{2}{*}{1.87} \\
\hline & + & $3.58 \mathrm{~b}$ & & $12.92 b$ & \\
\hline \multirow{2}{*}{$S$} & - & $2.28 \mathrm{a}$ & \multirow{2}{*}{9.30} & $7.73 \mathrm{a}$ & \multirow{2}{*}{2.82} \\
\hline & + & $2.19 a$ & & $8.07 \mathrm{a}$ & \\
\hline \multirow{2}{*}{$\mathrm{Cu}$} & - & $8.64 \mathrm{~b}$ & \multirow{2}{*}{4.58} & $27.31 \mathrm{~b}$ & \multirow{2}{*}{0.81} \\
\hline & + & $10.38 \mathrm{a}$ & & $41.48 \mathrm{a}$ & \\
\hline \multirow{2}{*}{$\mathrm{Fe}$} & - & $89.61 \mathrm{~b}$ & \multirow{2}{*}{1.34} & $296.60 \mathrm{~b}$ & \multirow{2}{*}{2.56} \\
\hline & + & $98.02 \mathrm{a}$ & & 365.98 a & \\
\hline \multirow{2}{*}{$\mathrm{Mn}$} & - & $222.94 \mathrm{a}$ & \multirow{2}{*}{2.07} & $729.33 b$ & \multirow{2}{*}{3.24} \\
\hline & + & $219.82 \mathrm{a}$ & & $812.37 \mathrm{a}$ & \\
\hline \multirow{2}{*}{ Zn } & - & $37.61 \mathrm{a}$ & \multirow{2}{*}{3.12} & $124.41 \mathrm{~b}$ & \multirow{2}{*}{0.76} \\
\hline & + & $36.47 \mathrm{a}$ & & $136.14 \mathrm{a}$ & \\
\hline
\end{tabular}

Data presented as averages of eight replicates. Means followed by the same letters did not present statistical differences between with and without AMF inoculation treatments for each nutrient. by the $t$ test (LSD) at 5\% probability of error 
Mycorrhizal colonization reduced phytonematode penetration. increased nodulation and nutrient uptake by soybeans. which is directly related to increased tolerance to nematode attack and higher plant growth (LIMA et al., 2015; SALGADO et al., 2016). Thus, maintenance of high AMF populations in soil may represent a strategy to stimulate plant growth and reduce nematode damage in soybean. For this, adoption of agricultural practices that stimulate soil biological activity is recommended, as crop rotation, permanent soil cover, reduction of soil compaction, erosion, pesticides and synthetic fertilizers, addition of large amounts of organic residues to soil, among others.

\section{CONCLUSIONS}

Mycorrhizal colonization by RhizoGlomus clarum can contribute to reduces Pratylenchus brachyurus penetration in soybean roots.

RhizoGlomus clarum mycorrhization increases nodulation, nutrient uptake and dry matter accumulation of soybean plants, in presence and absence of Pratylenchus brachyurus in soil.

Promoting mycorrhization is a strategy to reduce Pratylenchus brachyurus damage to soybean plants.

\section{ACKNOWLEDGMENTS}

This study was financed in part by the Coordenação de Aperfeiçoamento de Pessoal de Nível Superior - Brasil (CAPES) - Finance Code 001 and Conselho Nacional de Desenvolvimento Científico e Tecnológico - Brasil (CNPq).

The authors confirm that there are no conflicts of interest associated with this article.

\section{REFERENCES}

O PORTAL DO CONTEÚDO AGROPECUÁRIO - AGROLINK. (2019) NovaTero é a primeira empresa do Brasil a obter registro do MAPA para comercialização de inoculante. Disponível em: www.agrolink.com.br. Acesso em: 28 fev. 2019. 
ANZANELLO R, SOUZA PVD, CASAMALI B. Fungos micorrízicos arbusculares (FMA) em portaenxertos micropropagados de videira. Bragantia. 2011; (70): 409-6.

ASMUS G, FERRAZ LCCB. Effect of population densities of Heterodera glycines race 3 on leaf area photosynthesis and yield of soybean. Fitopalogia Brasileira. 2002; (27):273-5.

BELO MSSP, PIGNATI W, DORES EFGC, MOREIRA JC, PERES F. Uso de agrotóxicos na produção de soja do Estado do Mato Grosso: um estudo preliminar de riscos ocupacionais e ambientais. Revista Brasileira de Saúde Ocupacional. 2012; (37):78-10.

BONETTI JIS, FERRAZ S. Modificação do método de Hussey e Barker para extração de ovos de Meloidogyne exígua do cafeeiro. Fitopatologia Brasileira. 1981; (6):553-9.

BRESSAN W, SIQUEIRA JO, VASCONCELLOS CA, PURCINO AAC. Fungos micorrízicos e fósforo. no crescimento nos teores de nutrientes e na produção do sorgo e soja consorciados. Pesquisa Agropecuária Brasileira. 2001; (36):315-8.

BRIDA A; CORREIA ÉCSS; WILCKEN SRS. Susceptibility of soybean cultivars to the root lesion nematode. Summa phytopathol. 2017; (43):248-9.

BYRD, Jr. D. W.; KIRKPATRICK, J.; BAEKER, K. R. An improved technique for clearing and staining plant tissues for detection of nematodes. J Nematol. 1983; (15): 142-143.

CAMERON D, NEAL A, VAN WEES S, TON J. Mycorrhiza-induced resistance: more than the sum of its parts?. Trends in Plant Science. 2013;(18):539-6.

CASTILLO CG, OEHL F, SIEVERDING E. Arbuscular mycorrhizal fungal diversity in wheat agroecosystems in Southern Chile and effects of seed treatment with natural products. Journal of Soil Science and Plant Nutrition. 2016; (16):967-9.

COMISSÃO DE QUÍMICA E FERTILIDADE DO SOLO - CQFS-RS/SC. Manual de adubação e calagem para os Estados do Rio Grande do Sul e Santa Catarina. 11. ed. Porto Alegre: Núcleo Regional Sul da Sociedade Brasileira de Ciência do Solo; 2016. 400 p.

ELSEN A, GERVACIO D, SWENNEN R, DE WAELE D. AMF-induced biocontrol against plant parasitic nematodes in Musa sp.: a systemic effect. Mycorrhiza. 2008; (18):251-5.

FERREIRA DF. Sisvar: a Guide for its Bootstrap procedures in multiple comparisons. Science and Agrotechnology. 2014; (38):109-3.

FERREIRA PAA, CERETTA CA, SORIANIA HH, TIECHERA TL, SOARES CRFS, ROSSATO LV, NICOLOSO FT, BRUNETTO G, PARANHOS JT, CORNEJO P. Rhizophagus clarus and phosphate alter the physiological responses of Crotalaria juncea cultivated in soil with a high Cu level. Applied Soil Ecology. 2015; (91):37-10. 
FREITAS JRB, MOITINHO MR, TEIXEIRA DB, BICALHO ES, SILVA JÚNIOR JF DA, SIQUEIRA DS, BARBOSA BFF, SOARES PLM, PEREIRA GT. Soil Factors Influencing Nematode Spatial Variability in Soybean. Agronomy Journal. 2017; (109): 610-9.

GIOVANNETTI M, MOSSE B. An evaluation of techniques for measuring vesicular arbuscular mycorrhizal infection in roots. New Phytologist. 1980; (84):489-11.

HASHEM A, KUMAR A, AL-DBASS AM, ALQARAWI AA, AL-ARJANI A-BF, SINGH G, FAROOQ M, ABD ALLAH EF. Arbuscular mycorrhizal fungi and biochar improves drought tolerance in chickpea. Saudi Journal of Biological Sciences. 2018; (26):614-10.

HAYMANN DS, MOSSE B. Plant growth response to vesicular-arbuscular mycorrhiza l, growth of endogone inoculated plants in phosphate deficient soils. New Phytologist. 1971; (70):19-9.

JENKINS WR. A rapid centrifugal-flotation technique for separating nematodes from soil. Plant Disease Reporter. 1964; (48):692-6.

LIMA FSO, SANTOS GR, NOGUEIRA SR, SANTOS PRR, CORREA V. Population dynamics of the root lesion nematode Pratylenchus brachyurus in soybean fields in Tocantins state and its effect to soybean yield. Nematropica. 2015; (45):170-7.

MATSUO É, SEDIYAMA T, OLIVEIRA RDL, CRUZ CD, OLIVEIRA RCT. Avaliação de genótipos de soja em relação ao nematoide de cisto. Bragantia. 2012; (71):173-6.

MONDANI F, KHANI K, HONARMAND SJ, SAEIDI M. Evaluating effects of plant growth-promoting rhizobacteria on the radiation use efficiency and yield of soybean (Glycine max) under water deficit stress condition. Agricultural Water Management. 2019; (213):707-6.

EL MUJTAR V, MUÑOZ N, MC CORMICK BP, PULLEMAN M, TITTONELL P. Role and management of soil biodiversity for food security and nutrition; where do we stand?. Global Food Security. 2019; (20):132-10.

NICOLSON TH; WALKER C. The Glomeromycota: a Species List with New Families and New Genera. 1. ed. Gloucester. England: CreateSpace Independent Publishing Platform. 2010. 58p.

NORONHA MA, MUNIZ MFS, CRUZ MM, ASSUNÇÃO MC, CASTRO JMC OLIVEIRA ERL. MIRANDA CGS. MACHADO ACZ. Espécies de Meloidogyne e de Pratylenchus em áreas cultivadas com cana-de-açúcar no estado de Alagoas. Ciência Rural. 2017; (47):1-3.

PASARIBU A, MOHAMAD RB, HASHIM A, RAHMAN ZA, OMAR D, MORSHED MM. Effect of Herbicide on Sporulation and Infectivity of Vesicular Arbuscular Mycorrhizal (Glomus mosseae) Symbiosis with Peanut Plant. The Journal of Animal \& Plant Sciences. 2013; (23):1671-7.

PEREIRA MG, SANTOS CERS, FREITAS ADS, STAMFORD NP, ROCHA GSDC, BARBOSA AT. Interações entre fungos micorrízicos arbusculares, rizóbio e actinomicetos na rizosfera de soja.

Revista Brasileira de Engenharia Agrícola e Ambiental. 2013; (17):1249-7.

Ci. e Nat., Santa Maria, v.43, e3, 2021 
RASMUSSEN PU, CHAREESRI A, NEILSON R, BENNETT AE, TACK AJM. The impact of dispersal plant genotype and nematodes on arbuscular mycorrhizal fungal colonization. Soil Biology and Biochemistry. 2019; (132):28-7.

SALGADO FHM, MOREIRA FMS, PAULINO HB, SIQUEIRA JO, CARNEIRO MAC. Arbuscular mycorrhizal fungi and mycorrhizal stimulant affect dry matter and nutrient accumulation in bean and soybean plants. Pesquisa Agropecuária Tropical. 2016; (46):367-6.

SANTANA-GOMES SM, DIAS-ARIEIRA CR, BIELA F, CARDOSO MR, FONTANA LF, PUERARI HH. Sucessão de culturas no manejo de Pratylenchus brachyurus em soja. Nematropica. 2014; (44):200-6.

SCHNEIDER J, BUNDSCHUH J, NASCIMENTO CWA. Arbuscular mycorrhizal fungi-assisted phytoremediation of a lead-contaminated site. Science of the Total Environment. 2016; (572):86-11.

SCHOUTEDEN N, WAELE D, PANIS B, VOS CM. Arbuscular Mycorrhizal Fungi for the Biocontrol of Plant-Parasitic Nematodes: A Review of the Mechanisms Involved. Front Microbiol. 2015; (6):1280-9.

SMITH S, READ D. Mycorrhizal Symbiosis. 3. ed. San Diego: Academic Press. 2008. 605 p.

TCHABI A, HOUNTONDJI FCC, OGUNSOLA B, LAWOUIN L, COYNE D, WIEMKEN A, OEHL F. The influence of arbuscular mycorrhizal fungi inoculation on micro-propagated hybrid yam (Dioscorea spp.) Growth and root knot nematode (Meloidogyne spp.) Suppression. International Journal of Current Microbiology and Applied Sciences. 2016; (5):267-5.

VOS CM, TESFAHUN AN, PANIS B, WAELE D, ELSEN A. Arbuscular mycorrhizal fungi induce systemic resistance in tomato against the sedentary nematode Meloidogyne incognita and the migratory nematode Pratylenchus penetrans. Applied Soil Ecology. 2012; (61):1-6.

WANG X, PAN Q, CHEN F, YAN X, LIAO H. Effects of co-inoculation with arbuscular mycorrhizal fungi and rhizobia on soybean growth as related to root architecture and availability of $\mathrm{N}$ and P. Mycorrhiza. 2011; (21):173-8.

\section{Authorship contributions}

\section{1 - Edicarla Trentin:}

Doutora em Ciência do Solo pela Universidade Federal de Santa Maria http://orcid.org/0000-0002-6162-7881 - edicarla_15@yahoo.com.br

Contribution: Performed the experiments, Conceived and designed the analysis, Collected the data, Performed the analysis tools and drafted the manuscript

\section{2 - Valéria Ortaça Portela:}

Doutoranda em Ciência do Solo pela Universidade Federal de Santa Maria https://orcid.org/0000-0003-4940-5925 - valeriaortacaportela@gmail.com 
Contribution: Contributed data or analysis tools, Collected the data and drafted the manuscript

\section{3 - Juliane Schmitt:}

Doutoranda em Ciência do Solo pela Universidade Federal de Santa Maria https://orcid.org/0000-0002-8538-6189 - julianeschmitt@hotmail.com Contribution: Collected the data and drafted the manuscript

\section{4 - Reyllis Kiefer Unfer:}

Graduando em Agronomia pela Universidade Federal de Santa Maria, Bolsista de iniciação científica no Laboratório de Biologia e Microbiologia do Solo https://orcid.org/0000-0001-8467-8991 - reyllis9@gmail.com

Contribution: Collected the data

\section{5 - Zaida Inês Antoniolli:}

Doutora em Ecology Of Mycorrhizal Molecular Aspects pela The University Of Adelaide https://orcid.org/0000-0003-2036-8710 - zantoniolli@gmail.com

Contribution: Participated in design and coordination of the study and drafted the manuscript

\section{6 - Rodrigo Josemar Seminoti Jacques:}

Doutor em Ciência do Solo, Professor na Universidade Federal de Santa Maria https://orcid.org/0000-0002-8240-5145 - rodrigo@ufsm.br

Contribution: Participated in design and coordination of the study and drafted the manuscript

\section{How to quote this article}

TRENTIN, E.; PORTELA, V. O.; SCHMITT, J.; UNFER, R. K.; ANTONIOLLI, Z. I.; JACQUES, R. J. S. Suppression of Pratylenchus brachyurus and soybean growth inoculated with arbuscular mycorrhizal fungus, Ciência e Natura, Santa Maria, v. 43, e3, p. 1-17, 2021. DOI 10.5902/2179460X40961. Available from: https://doi.org/10.5902/2179460X40961. Accessed: Month Abbreviated. day, year. 